\title{
Shortage of pulses in India: understanding how markets incentivize supply response
}

\author{
Mathew Abraham and Prabhu Pingali \\ Dyson School of Applied Economics and Management, \\ Tata-Cornell Institute for Agriculture and Nutrition, Cornell University, \\ Ithaca, New York, USA
}

\section{Abstract}

Purpose - This paper aims to understand the significant farm and market-level factors that incentivize the adoption and marketing of pulses influencing its supply response to changing demand.

Design/methodology/approach - The authors first use a modified Nerlovian supply response model using secondary data to identify the major price and non-price factors influencing the supply of pigeon pea, black and green gram in the major pulses growing states in India. Second, using primary qualitative data the authors map the pulses value chain from farm to retail to identify the how proportional and fixed transaction costs (FCTs) influence market participation of pulses growers and limit the transmission of price and quality information. Findings - The supply response model shows some positive influence of price on area allocation for pigeon pea and black gram and some negative effects of yield and price increase of competing crops on pigeon pea acreage. However, for the most part, the area of Kharif pulses is inelastic to prices in the long run. Irrigation, rainfall and yields in the lag year are shown to have a significant influence on area allocation for pulses. The market study reveals that low yields, low landholding size and geographical disadvantages of high agroclimatic risk and poor connectivity hinder market access of pulses farmers relative to other crops. Market power in favor of buyers and poor price and quality information is a disadvantage to sellers, influencing their ability to participate in markets.

Research limitations/implications - A quantitative study would be required to identify the magnitude of farm and market-level transaction costs.

Originality/value - This study helps to understand the supply response of pulses and gives suggestions to direct policy to rectify this.

Keywords Pulses, Value chains, Transactions cost, Supply response, Food policy

Paper type Research paper

\section{Introduction}

Pulses are the most critical source of affordable dietary protein in India, where a significant portion of the population is poor. As a cheap, non-animal source of protein, pulses [1] have a prominent position in Indian diets, and the country is currently the largest producer, consumer and importer of pulses in the world. In the past decades, India witnessed a rapid rise in per capita incomes, driven by increasing economic opportunities arising from a booming service sector and rural wage improvement due to welfare schemes such as MGNREGA. This coupled with demographic change characterized by increase in population, life expectancy and women's participation in the workforce has led to an increasing demand for diverse food groups, away from staples, toward fruits and vegetables, dairy and meat and processed foods of higher value (Barrett et al., 2012; Hazell et al., 2010; Kumar and Kapoor,

(C) Mathew Abraham and Prabhu Pingali. Published by Emerald Publishing Limited. This article is published under the Creative Commons Attribution (CC BY 4.0) licence. Anyone may reproduce, distribute, translate and create derivative works of this article (for both commercial and non-commercial purposes), subject to full attribution to the original publication and authors. The full terms of this licence may be seen at http://creativecommons.org/licences/by/4.0/legalcode.
Shortage of pulses in India

Received 21 November 2017

Revised 24 July 2018

19 December 2018

20 December 2018

Accepted 31 December 2018 
JADEE 11,4

2014). The demand for pulses has also grown considerably in recent year (Rahman, 2015), but high fluctuations in supply and therefore prices of pulses, leading to recurring shortages in their availability.

Both price and non-price factors influence supply response in agriculture. Output price and the price of factors of production such as inputs, labor and land provide the incentives to produce crops for the market. In the Indian agricultural sector, non-price factors such as technological change, agro-climatic risk (Reddy, 2009; Sadasivam, 1993; Tuteja, 2006)and institutional problems of market access and poor price transmission (Rahman, 2015), rather than price factors is seen as having a significant influence on supply. However, price factors remain relevant. In 2015-16, however, an unprecedented increase in prices (40\% rise in wholesale price index (WPI)) led to a substantial increase in production of pulses. A country that has been producing an average of 16.1 million tons of pulses in the past decade produced 24 million tonnes in 2016-17 alone.

Understanding the factors that influence the supply response of a crop is essential for policy. Agricultural price policy in the form of minimum support price (MSP), subsidies for inputs, investments in yield increasing technology and infrastructure such as roads and irrigation and direct market procurement have all been interventions to ensure supply responses especially for major staple grains such as wheat and rice. In this paper, in order to see why only unrealistically large price rise can influence a production response, we look at farm-level and market-level factors influencing the supply response in prices. First, using a modified Nerlovian supply response model, we identify the price and non-price factors influencing acreage response in pulses. We find that some price response (positive) in the case of pigeon pea and black gram and yield and price influence (negative) of competing crops on pigeon pea acreage. However, for the most part, the area of Kharif pulses is still inelastic to prices in the long run. Irrigation, rainfall and yields in the lag year are shown to a significant influence on area allocation for pulses.

The supply response model, however, does not capture transaction costs and its influence on supply in pulses. The level of participation in markets determines the farm-level supply response. Using qualitative data gathered from mapping the value chain from farm to markets from six primary pulses growing states, we argue that transaction costs due to low economies of scale, poor connectivity to markets or high cost finding buyers, negotiating price and selling, influences whether farmers participate or limit their participation in markets. We also find that the level of commercialization may influence farm-level investments and access to technology to improve production. We highlight the importance of aggregation models to address issues of economies of scale, market reforms in the form of vertical coordination, establishing grades and standards-based transactions and the improvement of infrastructure for connectivity to as suggestions to reduce transaction costs. This will enable better transmission of prices, incentivizing supply responses in line with changing demand.

\section{Production and price volatilities in pulses - the role of transaction costs in influencing supply} Income and population growth are the main drivers of food demand (Pingali, 2007; Tschirley et al.,2015). Productivity growth of crops proportional to the rising population and increasing purchasing power resulting from income growths is essential to assure the availability of various food groups. The green revolution was instrumental in improving the productivity of major staples such as wheat and rice, to assure availability and achieve food security in the calorific sense. For other crops such as pulses, the area under cultivation, production and yields have shown to be virtually stagnant. Table 1 shows the decade-wise mean of the area, productivity and yield of wheat, rice, pigeon pea, black gram and green gram. The area and 


\begin{tabular}{|c|c|c|c|c|c|c|c|}
\hline & & $1970-80$ & $1980-90$ & $1990-00$ & $2000-10$ & $2010-17$ & Shortage of \\
\hline \multirow[t]{3}{*}{ Rice } & Area & 38.64 & 40.65 & 43.22 & 43.41 & 43.62 & \\
\hline & Production & 44.76 & 59.78 & 80.10 & 89.19 & 104.68 & \\
\hline & Yield & 1156.17 & 1467.09 & 1849.70 & 2052.41 & 2399.26 & \\
\hline \multirow[t]{3}{*}{ Wheat } & Area & 201.08 & 232.57 & 255.37 & 268.98 & 302.96 & \\
\hline & Production & 277.80 & 446.54 & 639.09 & 733.55 & 926.34 & \\
\hline & Yield & 1374.90 & 1916.70 & 2494.70 & 2724.40 & 3058.86 & 413 \\
\hline \multirow[t]{3}{*}{ Pigeon pea } & Area & 2.59 & 3.19 & 3.48 & 3.51 & 4.19 & \\
\hline & Production & 1.81 & 2.38 & 2.39 & 2.43 & 3.13 & \\
\hline & Yield & 703.10 & 745.00 & 687.00 & 690.80 & 742.09 & \\
\hline \multirow{3}{*}{ Green gram } & Area & 2.30 & 3.00 & 3.04 & 3.20 & 3.47 & \\
\hline & Production & 0.73 & 1.18 & 1.19 & 1.11 & 1.64 & \\
\hline & Yield & 314.50 & 392.80 & 390.88 & 343.67 & 474.69 & \\
\hline \multirow[t]{3}{*}{ Black gram } & Area & 2.18 & 3.03 & 3.05 & 3.13 & 3.44 & $\begin{array}{r}\text { Iable } \\
\text { Decade-wise means }\end{array}$ \\
\hline & Production & 0.69 & 1.23 & 1.39 & 1.36 & 2.00 & $\begin{array}{l}\text { Decade-wise means of } \\
\text { the area, productivity }\end{array}$ \\
\hline & Yield & 316.61 & 404.80 & 457.39 & 435.04 & 578.53 & and vield of selected \\
\hline \multicolumn{7}{|c|}{ Note(s): " area - million Ha; Production - million tonnes; yield -kg/ha } & pulses and cereals \\
\hline
\end{tabular}

yield under wheat have shown the highest growth over the decades, followed by rice while the area under production for pulses have remained unchanged, while yields have shown fluctuation from 1980 to 2010. Between 2010 and 2017 we see improvements both productivity in yields for all pulses.

Low productivity growth of pulses and increasing population has led to a decrease in the availability of pulses. Low availability coupled with increasing demand has led to high price volatility in pulses. The per capita availability of pulses decreased from an average of $65 \mathrm{~g} /$ day in the 1950s to $35 \mathrm{~g}$ in 2010 with high levels of year on year variations (Figure 1). Figure 2 shows the monthly WPI of primary Kharif pulses and wheat and rice between 2004 and 2016. In comparison, the WPI of pigeon pea, green gram and black gram is shown to have high variation without much domestic production response until 2015-16. Since 2000-01, import of pulses has played a significant role in improving the availability of pulses. Between 1990 and 2000, India's average yearly import of pulses was 0.58 million tonnes compared to 2.1 million tonnes per annum between 2000 and 2010 .

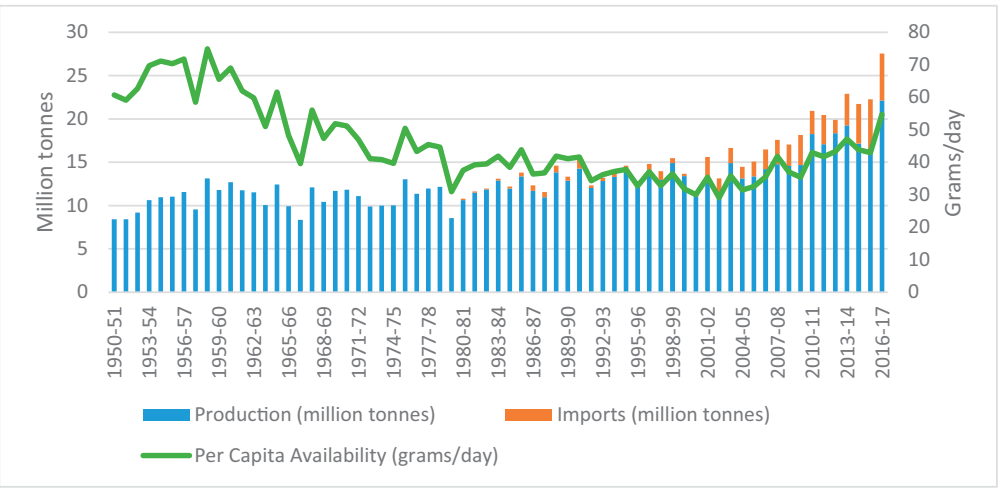

Figure 1.

Production, imports and per capita availability of pulses from 1950 to 2017

Source(s): Ministry of Agriculture, Government of India 


\section{JADEE 11,4}

\section{4}

Figure 2.

WPI volatility of Pulses and major cereals (2004-17)

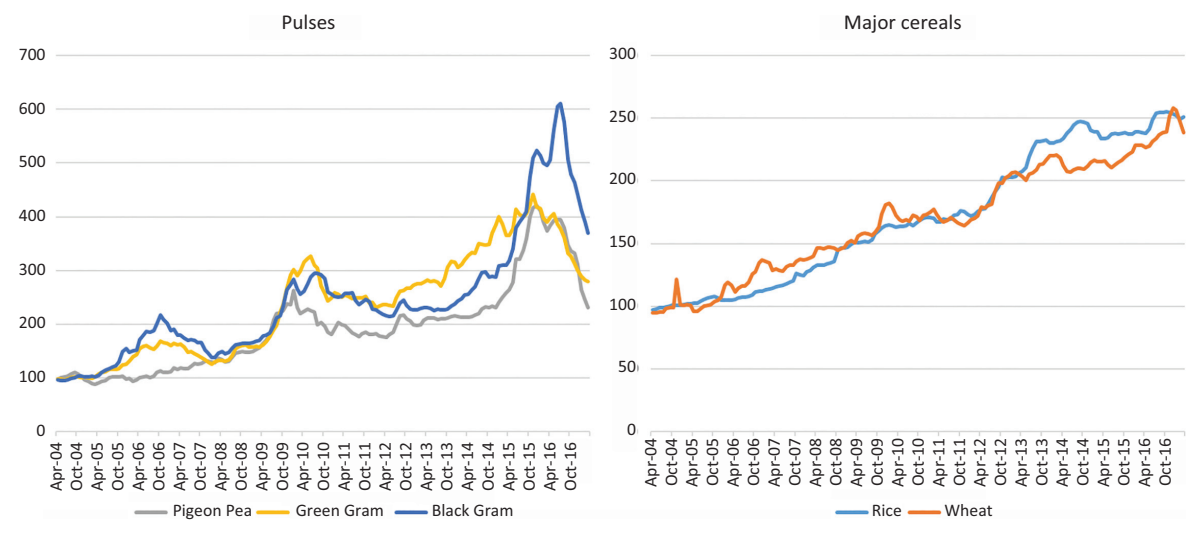

A sharp unprecedented rise in the prices of pulses between 2014 and 2016 resulted in a sudden increase in production and import of pulses. From December 2012 to December 2015, the WPI of pigeon pea, green gram and black gram grew by $95 \% 32$ and $119 \%$ respectively. In response to this, the area under pulses cultivation grew from 24 million hectares in 2015-16 to 29 million hectares in 2016-17. In 2015-16, India also imported 5.7 million tonnes of pulses to meet the deficit in production. Increase in production and imports led to the increase of per capita availability of pulses to $54.7 \mathrm{~g}$ per day in 2016-17. In 2017-18, the record production sent the WPI of pulses down by $26 \%$. The decrease in price is expected to drive down production again in 2018-19.

\subsection{Supply response - Nerlovian and the transaction cost approach}

The production responsiveness of farmers to changing demand is conditioned on the economic incentives to grow a particular crop. In economics, both the supply function and supply response are measures of incentives; however, while the supply function looks at the relationship between output and price, the supply response looks at price factors and other supply shifters as incentives for increased production (Nerlove, 1958). Price factors comprise of input and output price characteristics that determine cost of production and profit, while supply shifters are exogenous factors such as availability of technology, biophysical conditions such as rainfall irrigation, infrastructure and market access (Key et al., 2000a, b; Yu et al., 2012) that determine, yield and production risks. Nerlov (1958) first studied the influence of expected future price on-farm decision to grow cotton, corn and wheat in the United States. In the Indian context, studies have shown that the supply response to price is poor (Alagh, 2004; Kanwar, 2006; Palanivel, 1995; Tuteja, 2006) and others have observed technology variables (Desai and Nambooditi, 1997; Mungekar, 1997; Thamarajakshi, 1994), rainfall and access to irrigation (Kanwar, 2006; Tuteja, 2006) are essential in influencing supply.

Institutions such as markets also play a role in determining supply response of producers. The ability to access markets influences the level of commercialization of farms, which refer to the level of participation in input markets to access factors of production such as credit, quality inputs, technology, labor and output markets to sell the produced agricultural goods (Pingali and Rosegrant, 1995). Higher levels of commercialization entail the creation of marketable surplus and participation in markets. The participation in markets by farming household is heterogeneous as producers are commercialized, semi-commercialized or subsistence (Pingali and Rosegrant, 1995; Key et al., 2000a, b). Commercialized households buy inputs and sell outputs in the markets, while semi-commercialized farms would buy and 
sell only a proportion of inputs and produce and subsistence households may not participate in markets.

Differential market participation and therefore supply response can be influenced by transaction costs (Pingali et al., 2005). Key et al. (2000a, b) classifies transaction costs for agricultural households influencing supply as proportional and fixed transaction costs (FCTs). Proportional transaction cost (PCT) is the per unit cost of market access such as transportation, imperfect information that varies according to crops (dependent on yields) location (distance to markets and biophysical risks) and farm and household specific (landholding size, gender and education determined) factors (Pingali et al., 2005). It raises the effective price of paid buyers and lowers the price received by sellers creating a price band within which some households will not participate in markets (de Janvry et al., 1991) as costs outweigh benefits. FCTs are size invariant and therefore not determined by the quantity of goods exchanged (Goetz, 1992). Cost of searching for buyers and markets, negotiating and bargaining costs, screening costs (in the case of land, labor, inputs or credit) are considered significant fixed costs that will influence the decision of households to participate in markets.

In the Indian context, pulses have been noted to have a weak price response, unless large enough to offset production and marketing risks (P. Joshi et al., 2016). An increase in production of pulses in response to high prices by 8 million tonnes in the year 2017-18, is an example. The influence of non-price factors such as droughts, access to high yield varieties of seeds and irrigation has also been noted to influence supply (Reddy, 2009). However, understanding how access to markets influence supply response in pulses has not been studied. In this paper, we first estimate the effects of price, farm-level non-price and risk factors influencing area allocation for pigeon pea, green and black gram through a confirmatory analysis and then we qualitatively explore the factors influencing market access and transaction costs and its influence on the supply response of pulses.

\section{Method}

In order to understand the factors influencing the supply response of primary Kharif pulses in India, the paper first estimates a modified Nerlovian supply response model, with statelevel fixed effects to control for unobserved characteristics. We also compute the short and long run elasticity of price for pigeon pea, green gram and black gram. The model helps determine the important price and non-price factors at the farm level that influence the supply of pulses in India. The paper then uses a qualitative approach to understand the various transaction costs to determine the market-level factors influencing the supply of pulses. A qualitative approach was chosen for two reasons. First, agricultural markets are complex and are highly fragmented with a large number of participants undertaking specific roles and functions. This approach was ideal for mapping this structure, to capture its complexities that would allow us to define and determine the nature of fixed and proportional transactions costs (Donovan et al., 2015) in the marketing of pulses. Second, at the market level, many of the transaction processes that were undertaken were at an informal level. The role of merchants and traders were ambiguous and secretive. Access to information about their roles and activities required anonymity and trust and as a result, the study had to rely on a small number of key informants.

\subsection{Data}

Data for the supply response model was accessed from the Central Statistics Office (CSO), the Ministry of Statistics and Programme Implementation and the Ministry of Agriculture, Government of India. The model uses data for pigeon pea, green gram and black gram from 1970 to 71 to $2015-16$. The leading states producing these pulses and the competing crops 
JADEE 11,4 growing in the Kharif season are given in Table A1. Qualitative data for the study was collected in the states of Bihar, Odisha, Uttar Pradesh, Delhi, Madhya Pradesh and Maharashtra. This study was conducted in two phases.

The first phase of the study was carried out from January to March of 2016 when the prices of pulses were at an all-time high and the second phase of the study was done between November 2016 and January 2017, when the price of pulse had considerable dipped. In the first phase of the study, we carried out focus group interviews in 16 villages in three districts of Odisha, Bihar and Uttar Pradesh as a part of a more extensive study to identify interventions to promote an affordable, nutrition-sensitive foods system (Table A2). The study helped identify the dominant issues related to the adoption of pulses in these regions and the transaction costs influencing pulses growing at the farm level. We also visited the main pulses markets of Naya Bazaar (in Delhi), Bhopal, Pipariya and Bankhedi (in Madhya Pradesh) to understand the dynamics involved in the marketing of pulses. The preliminary findings from the first phase helped design and guide the second phase of the study. In-depth interviews and discussions were conducted with various market players and an additional nine focus group interviews were conduction with 25 farmers in different markets in the states of Madhya Pradesh and Maharashtra to identify production and marketing challenges in pulses. Table A3 lists the ten pulses markets we visited during both phases for this study and the various participants from whom information was collected.

\subsection{Model specification}

The Nerlovian expectation model posits that the farmers' future price expectation shape their decision to allocated land to particular crops (Nerlove, 1958). Here we hypothesize that farmers allocation of land to a particular crop is determined by expected profit, production risk, price and yields of competing crops. A number of studies using time series data have assessed the responsiveness of area under cultivation under a particular crop to changes in prices in the lagged year (Ashok, 2004; Cummings, 1975; Kanwar, 2006; Parikh, 1972), characteristics of competing crops (Kanwar, 2006; Yu et al., 2012) and exogenous risk variables (Behrman, 1968; O. Singh, 1998) to assess how farmers respond to changes in price and non-price factors. In the model, we use the area as the dependent variable and a set of price (for selected pulses and the competing crop) and non-price (irrigation, rainfall and yield) and risk parameters (coefficient of variation of price and rainfall) as the dependent variables.

The model is specified as (1)

$$
\begin{aligned}
\log A_{i t} & =\beta_{0}+\beta_{1} \log P_{i t}-1+\beta_{2} \log I_{i t}+\beta_{3} \log R_{i t}+\beta_{4} \log Y+\beta_{5} \log A_{i t-1}+\beta_{6} \log C P_{i t-1} \\
& +\beta_{7} \log C Y_{i t}+\beta_{8 \rho P}+\beta_{9 \rho R}+u_{i t}
\end{aligned}
$$

where

$\log A_{i t}$ is the area under cultivation in state ${ }_{I}$ in year ${ }_{i}$;

$\log P_{i t-1}$ is the wholesale price index of the crop in state ${ }_{i}$ in year $t-1$;

$\log I_{i t}$ is the area under irrigation of the particular crop in state $I$ in year $t$ (in 1000 ha),

$\log R_{i t}$ is the rainfall received in state in year $_{t-1}$,

$\log Y_{i t-1}$ is the yield of the crop in state ${ }_{I}$ in year ${ }_{t-1}$ and

$\log A_{i t-1}$ area under cultivation in state in year $_{t-1}$.

$\log C Y_{i t-1}$ is the yield of the competing crop in state in year $_{t-1}$ and

$\log C P_{i t-1}$ wholesale price index of the competing crop in state ${ }_{\mathrm{i}}$ in year $t-1$. 
Variables $\rho_{P}$ and $\rho_{R}$ coefficient of variation of the price of the crop and rainfall received respectively.

The paper also computes the long-term elasticity of area under cultivation. The long-term price elasticity where producers have more time to adjust to the area was calculated as follows (3)

$$
\varepsilon_{L R}=\frac{\beta_{1}}{\sigma}
$$

where the coefficient of adjustment $\sigma$ is (4)

$$
\sigma=1-\frac{\partial \log A_{i t}}{\partial \log A_{i t-1}}
$$

\section{Results}

Tables 2 and 3 shows the results of the specified model. We find that lagged price has a significant effect on supply (area under cultivation) of pigeon pea and black gram and not for green gram. The price of the lagged competing-crop had a significant negative effect on the area under pigeon pea, which means a higher price of competing crops in the preceding year, reduces land allocation to growing pigeon pea in the current year in primary states. The longer duration of the growing season ( 7 months) in relation to other pulses ( 3 months) may explain why the higher price of competing crops influence reduced cultivation of pigeon pea in particular. Section 5.2.1 explains how the per unit cost of production is higher in pulses such as pigeon peas compared to cotton and soybean, incentivizing their cultivation at the cost of pulses. Despite seeing a price effect, the long-term elasticity is less than one; therefore, the area under pulse cultivation is seen to be price inelastic in the long term.

\begin{tabular}{lccc}
\hline Independent variables & Pigeon pea & Black gram & Green gram \\
\hline $\mathrm{P}_{i t-1}$ & $0.1503^{* * * *}$ & $0.2321^{* * *}$ & 0.1217 \\
$\mathrm{I}_{i t}$ & $0.1954^{* * * * *}$ & $-0.0871^{* * *}$ & $0.1928^{* * * *}$ \\
$\mathrm{R}_{i t}$ & $0.334^{* * *}$ & -0.0593 & 0.0433 \\
$\mathrm{Y}_{i t-1}$ & $0.1949^{* * *}$ & $0.0954^{* *}$ & $0.1525^{* * *}$ \\
$\mathrm{~A}_{i t-1}$ & $0.2854^{*}$ & $0.4598^{* * *}$ & 0.5074 \\
$\mathrm{CP}_{i t-1}$ & $-0.3132^{* * *}$ & -0.0743 & -0.1751 \\
$\mathrm{CY}_{i t-1}$ & $-0.1949^{* * *}$ & -0.0971 & $\mathrm{dd}$ \\
$\rho_{P}$ & 0.00315 & $0.0049^{* *}$ & 0.0019 \\
$\rho_{R}$ & $0.0041^{* *}$ & $-0.0069^{* * *}$ & -0.0049 \\
Intercept & $2.3581^{* * *}$ & $3.5082^{* * *}$ & 0.1343 \\
$N$ & 314 & 262 & 237 \\
Note(s) ${ }^{*}{ }^{* *}{ }^{* * *}$ Significant at 1,5 and 10 percent levels, respectively &
\end{tabular}

Note(s): ${ }^{*}{ }^{* *},{ }^{* * *}$ Significant at 1,5 and 10 percent levels, respectively

$$
\text { the area under pulse cultivation is seen to be price inelastic in the long term. }
$$

\begin{tabular}{lcc} 
& \\
& & \\
\hline Pulses & Long run elasticity & \\
\hline Pigeon pea & 0.2103 & $\begin{array}{r}\text { Table 3. } \\
\text { Black gram } \\
\text { Green gram }\end{array}$ \\
\hline
\end{tabular}


JADEE 11,4

418

Availability of Irrigation was significant for all pulses but negatively significant for black gram, while rainfall was significant only for pigeon pea. Both black and green gram are more resilient in growing in rainfall conditions and the being short duration crops ( 3 months) may be why rainfall did not have a significant effect. The negative relation for black gram could again be a substitution effect, where farmers decide to grow other crops when there is better access to irrigation or rainfall.

Previous experience of farmers influences their decision to grow pulses in the current season. The reason for this is farmers anchor their expected output based on experience. In this model, we used area and yield data of the previous year to see its influence on supply. Previous years yield had a significant effect of farmer's decision to allocate land for both pigeon pea and green gram while previous year's area under production has a significant effect on black gram. The yield of the competing crop in the previous year, like the price, has a negative effect of pigeon pea as a $1 \%$ increase in the price of the competing crop reduces the area under pigeon pea by $0.19 \%$.

Despite area showing a price effect for black gram and mildly for pigeon pea, the supply is mostly price inelastic. Although the model captures allocation decisions, biophysical influences and risk factors, it does not capture factors influencing the decision to participate in the markets. In this fixed effects model, although the omitted variable bias is addressed, it is limited in explaining the influence of other factors such as transaction costs on supply response. Understanding the influence of transaction cost on different crops will help understand the substitution effects of competing crops at the farm level and supply inelasticity. In the next part of this paper, using qualitative data, we assess the main transaction costs potentially influencing market participation among smallholder pulses producers.

\section{Structure of markets and transaction costs of pulses- understanding market- level factors influencing supply}

As demand for food groups increase due to income and population growth, commercialization of small farms or increased engagement with markets becomes essential for supply to match demand (McCullough et al., 2008; Pingali, 2010; Pingali and Rosegrant, 1995). The ability of producers to respond to demand is conditioned by the producers' capacity to participate in markets. Well-functioning markets relay price and demand information of the consumer to producers influencing supply responses. In many developing countries, the ability of producers, especially small and marginal producers to participate in markets is conditioned by transaction costs. Using the example of the main Kharif pulses in India, we look at the significant factors influencing the ability of producers to commercialize and respond to prices. Using qualitative data collected from main pulses growing regions and markets, this section maps the structure of pulses markets from farm to retail, identifies the various fixed and PCTs that influence access to markets and price realization.

\subsection{Structure of pulses markets and factors influencing smallholder market participation}

Agricultural markets in India and many developing countries are complex in institutions owing to the many forms of production linkages and exchange relations that exist in them (Benjamin et al., 2002). Exchange relations in these highly fragmented markets are not based on price terms alone as they can be influenced by social factors such as caste, gender and religion. (Bharadwaj, 1985; Thorat, 2009; Thorat and Newman, 2007). In the process of commercialization where there is increased engagement with markets, producers access both input and output markets (Figure 3). From the input markets, farmers access to credit and inputs such as seeds, pesticides, fertilizers, labor and technology. Both formal and informal 


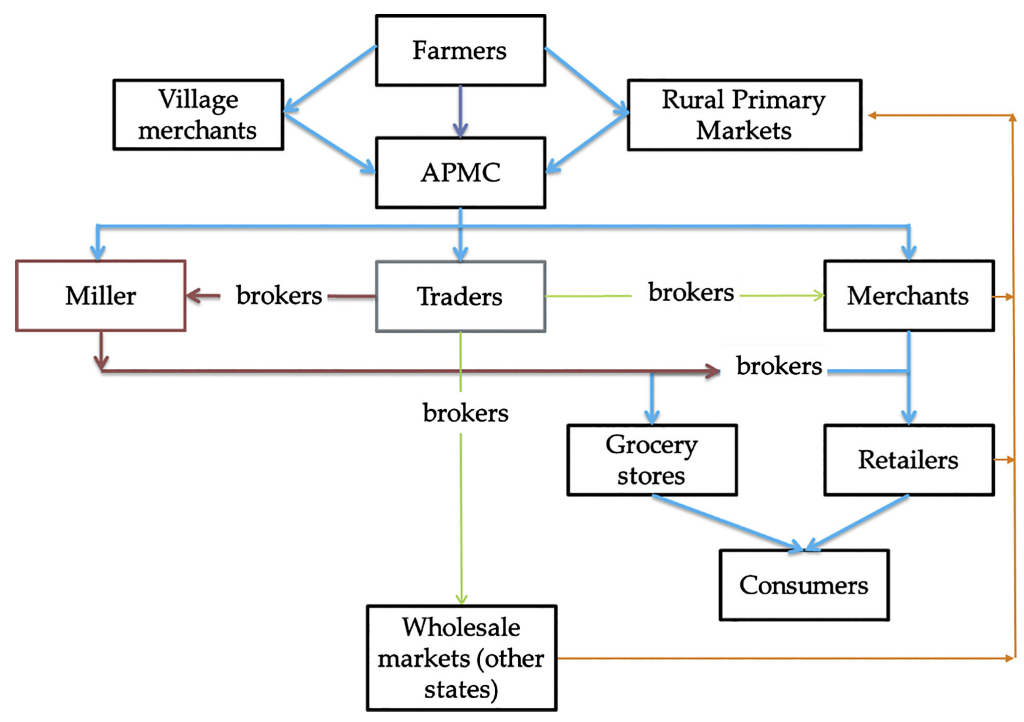

\section{Shortage of pulses in India}

actors participate in these markets. Formal actors are banks, government agencies and retailer who provide credit, inputs and extension related services. When access to formal institutions are weak; moneylenders, input dealers and other intermediaries become agents providing these services.

The structure of output markets differs depending on the agricultural produce (Routroy and Behera, 2017). Wet markets for perishables such as fruits and vegetables, flowers and fish often have shorter supply chains due to time constraints in marketing. For nonperishable crops, the value chains can be long and fragmented as is the case with pulses. The traditional market value chains comprise of rural primary markets (RPMs), the agricultural produce marketing committee (APMC) or the secondary markets and the wholesale markets. However, the first line of sales is the village merchants to whom farmers sell their produce at the farm gate. RPMs are primarily informal, periodic markets referred to as haats or melas and only about $15 \%$ of the 27,294 RPMs is India is regulated by rules and codes of conduct to guide sales (Acharya, 2006). In these markets both buying and selling takes place and farmers may sell raw pulses and also buy processed pulses for household consumption. RPMs serve a cluster of villages and are convenient for producers with limited surpluses hindered by distance. However, in these markets producers may get a higher price than selling to village merchants. The main buyers in these markets are village level merchants who procure at the farm gate when volumes of produce are low, or distances to markets are considerable.

Secondary markets or AMPCs conducts a majority of the regulated market exchange for agricultural produce. Referred to as mandis, their primary function is to regulate market practices such as weighing, sale, grading and payment. Currently, there are over 2170 APMC in India. The primary sellers are farmers (or traders who pose as farmers) and buying from them are different traders, millers or wholesale merchants. The traders consolidate produce in these markets in wholesale markets. They have different buying and selling capacities and may vary from traders' transaction large volumes to petty traders with smaller volumes of pulses. With pulses that do not require processing such as green and black gram, traders sell to wholesale or retail markets. Wholesale markets are large markets, specific to commodities and products such as cereals, pulses and vegetables. Located in major urban centers, it is from 
JADEE 11,4 these terminal markets, smaller grocery stores or the mom and pop stores often buy pulses. The primary participants in these markets are wholesale traders, importers, millers and merchants.

\subsection{Smallholder production and proportional transaction costs for pulses}

The primary determinant influencing farm linkages to markets are surpluses and the costs of market access. In the wake of infrastructure constraints in the form of poor connectivity or vast distances to markets to the cost of market access is high. Farmers with sufficient surpluses may choose to take their produce to the RPMs or secondary markets, while smaller farmers sell to village merchants at the farm gate. The yield of crops, the size of landholdings and location of farms, therefore, play a critical role in market participation. As these factors differ from farm to farm, they influence the unit cost of market access. In this section, we see how these PCTs can be crop, location and household specific in nature and how they influence the marketing of pulses.

5.2.1 Crop specific factors and transaction costs influencing pulses adoption. Policy and institutional support for cereals following the green revolution have had a significant influence on the patterns of pulses cultivation in India. Availability of high yielding variety (HYV) seeds, technical support and assured procurement for the public distribution system (PDS) made growing of wheat and rice more lucrative. The inelastic supply of land and the limited availability of irrigation facilities have lowered the priority of pulses which did not witness much yield growths and more productive lands began being allocated to growing cereals. In states like Punjab, Haryana and UP, where irrigation infrastructure was available, Sadasivan (1989) found that there was a sharp decrease in the adoption of pulses under irrigated conditions in favor of rice and wheat. Assured prices and the availability of water made it favorable to grow more cereals and this led to a decline intercropped legumes and pulse (Goldman and Smith, 1995). Better quality and productive land were used to grow cereals and pulses cultivation shifted to marginal poor quality lands or regions dependent on rain-fed agriculture (Reddy, 2009).

In small farms, the yield of crops is crucial for incomes and crop planting choice. When yields are low, the cost of production per quintal is high. Table 4 shows the cost of production of for cereals, selected pulses along with soybean and cotton in the states of Maharashtra and Madhya Pradesh. Although the inputs other than seeds may not be different across crops and in some cases lower for pulses, low yields result in higher cost of production per quintal compared to cereals and cash crops. This variation in costs can lead to a strong substitution effect in the supply model results in section 4.

Farmers report their preference for cereals, cotton and soybean over coarse cereals and pulses due to lower yield realization and higher production risks.

Sometimes moong (green gram) is profitable and sometimes tur (pigeon pea). It is unpredictable. However, growing wheat is a predictable process and I think predictability has made it comfortable to grow wheat - Sobran Singh, a farmer in the Bankhedi market, Madhya Pradesh

Tur (pigeon pea) is no seen as the main crop although it is a traditional crop. Inputs especially seeds and pesticides have always been a problem. Other crops like cotton and soya have different hybrids and different qualities by this are limited for tur. So they become preferable-Manish Selkar, Farmer, Hinganghat, Maharashtra

The higher cost of cultivation per quintal for pulses compared to competing crops such as maize and soybean could explain some of the substitution effects in the supply response model results in section 4. Uncertain yields lower incentives to participate in markets (Bhattarai et al., 2013). We see that higher lagged yield and price of competing crops reducing the area under cultivation for pigeon pea. At the farm-level per unit cost can be economized 


\section{JADEE 11,4}

\section{2}

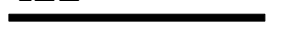

Black

gram

Table 5.

Percentage distribution of output sold by type of agency (2013)

\begin{tabular}{|c|c|c|c|c|c|c|c|}
\hline Crop & $\begin{array}{c}\text { Size of } \\
\text { landholdings }\end{array}$ & $\begin{array}{l}\text { Village } \\
\text { merchant }\end{array}$ & $\begin{array}{l}\text { Mandi } \\
\text { trader }\end{array}$ & $\begin{array}{l}\text { Input } \\
\text { dealer }\end{array}$ & $\begin{array}{l}\text { Cooperatives and } \\
\text { government } \\
\text { agencies }\end{array}$ & Processors & Others \\
\hline Pigeon & $<0.5$ & 69 & 30 & 0 & 0 & 0 & 1 \\
\hline \multirow[t]{3}{*}{ pea } & $0.5-1.0$ & 34 & 51 & 11 & 0 & 0 & 4 \\
\hline & $>1.0$ & 31 & 62 & 6 & 0 & 0 & 0 \\
\hline & All sizes & 31 & 61 & 7 & 1 & 0 & 0 \\
\hline Black & $<0.5$ & 91 & 4 & 5 & 4 & 0 & 0 \\
\hline \multirow[t]{3}{*}{ gram } & $0.5-1.0$ & 50 & 45 & 1 & 0 & 0 & 1 \\
\hline & $>1.0$ & 56 & 39 & 5 & 0 & 0 & 0 \\
\hline & All sizes & 63 & 32 & 5 & 1 & 0 & 0 \\
\hline Green & $<0.5$ & 85 & 1 & 9 & 0 & 0 & 4 \\
\hline \multirow[t]{3}{*}{ gram } & $0.5-1.0$ & 54 & 41 & 5 & 0 & 0 & 0 \\
\hline & $>1.0$ & 45 & 52 & 2 & 0 & 0 & 0 \\
\hline & All sizes & 47 & 51 & 2 & 0 & 0 & 0 \\
\hline
\end{tabular}

Source(s): National Sample Survey (NSS) 70th round

\section{Table 6.}

Number per 100 agricultural households aware of MSP, procurement agency and sale by agency

\begin{tabular}{lccc}
\hline & Aware of MSP & Aware of procurement agency & Sold to procurement agency \\
\hline Paddy & 322 & 251 & 135 \\
Jowar & 83 & 63 & 17 \\
Bajra & 160 & 102 & 30 \\
Maize & 106 & 76 & 42 \\
Ragi & 25 & 25 & 4 \\
Pigeon pea & 46 & 38 & 13 \\
Black gram & 57 & 37 & 16 \\
Green Gram & 98 & 72 & 310 \\
Sugarcane & 398 & 361 & 11 \\
Groundnut & 64 & 45 & 36 \\
Soyabean & 79 & 154 & 69 \\
Cotton & 204 & 57 & \\
Source(s): National Sample Survey (NSS) 70th round &
\end{tabular}

reference price. Awareness of procurement agency in Kharif pulses were low and sales to procurement agency even lower.

PCTs also influence opportunity cost for small and marginal households especially in regions with poor access to irrigation and high agro-climatic risks (Haberfeld et al., 1999). In semi-arid regions, seasonal out-migration during lean seasons contribute to about a third of household incomes (Harriss-White and Garikipati, 2008). Seasonal migration, therefore, is a risk-reducing strategy especially for households located in chronically poor regions (Deshingkar, 2010).

The impact of this on cultivation has been varied. In the tribal regions of Kandhamal for example, group discussions with farmers conducted in six villages of Damengi, Jakamaha, Dadadimaha, Dandikia, Kalungia and Tandalanju revealed that out-migration and shortage of household labor had reduced cultivation to one growing season. The land in the post-paddy season, which was used to grow pulses, mainly black and green gram are left fallow. Off-farm labor costs being higher than returns from farms in these regions limited the adoption of pulses and this is accentuated by open grazing practices in livestock and shortage of labor in the non-paddy seasons. 
5.2.3 Locational challenges and transaction costs in pulses cultivation. The spatial features of farms characterized by its location, climatic conditions and the level of connectivity (road and communication infrastructure) influence the levels of risk in cultivation and the cost of accessing factor and product markets. In lower potential areas or areas with poorer infrastructures (roads, irrigation, storage) and higher agro-climatic risks have increased costs of accessing inputs such as credit and context-specific technologies. Compared to sugarcane (95.3\% under irrigation), wheat (93.6\% under irrigation) and rice (59.6\% under irrigation), both coarse grains and cereals are grown in unirrigated conditions. Only $19.7 \%$ of the area under pulses (except gram) and $17.2 \%$ of the area under coarse grains come under irrigation. $35 \%$ of gram cultivation is under irrigated condition primarily because they are intercropped with wheat in some regions. In comparison, only $4.3 \%$ of the area under pigeon pea is under irrigation [2]. In pulses, while the lack of timely rainfall or irrigation is a concern, the problem of excessive or unseasonal rainfall is also a problem.

Many times, failure of the pulses crop comes from too much rainfall rather than too little. This is mainly in the case of pigeon pea, green gram and black gram. Once there is water damage, there is no way to recover the crop, unlike if there are too little rains, yields will be low, but we will get something. Some farmers shift to maize to prevent this risk Vijayandra Prajapat, Farmer, Timarni, Madhya Pradesh

The NSS data show that pigeon pea has the highest risk to low rainfall and drought compared to green and black gram (Table 7). Black gram is shown to be the least affected level of rainfall, and this could explain the negative association between irrigation and area under cultivation for black gram in the supply model in section 4 . Due to low rainfall risks, black and green gram could make ideal crops for cultivation in low potential areas, if yields can be improved to offset on farm opportunity costs. Increased access to irrigation may lead to substitution rather than increased cultivation of pulses due to lower yields.

Marketing costs in regions of poor connectivity are high. In the dominant pulses growing regions such as Rajasthan, Madhya Pradesh, Orissa the density of APMCs are lower and the reliance on RPMs and village merchants are high. Acharya (2006) notes that the average area an APMC year serves is around 459 sq.km. However, in states such as Assam, Himachal, Orissa, Madhya Pradesh and Rajasthan this area is considerably larger.

When the major markets are far from the farm and the roads connecting them are not good, farmers choose to sell in either the local market or at the farm to local traders. They know they will get 300-

\begin{tabular}{lcccrc}
\hline Crop & $\begin{array}{c}\text { Size of } \\
\text { landholdings }\end{array}$ & $\begin{array}{c}\text { Inadequate rainfall } \\
\text { drought }\end{array}$ & $\begin{array}{c}\text { Disease/animal/ } \\
\text { insect damage }\end{array}$ & $\begin{array}{c}\text { Other natural } \\
\text { causes }\end{array}$ & Others \\
\hline Pigeon & $<0.5$ & 81.70 & 10.60 & 7.70 & 0.00 \\
pea & $0.5-1.0$ & 63.40 & 18.60 & 15.00 & 3.00 \\
& $>1.0$ & 79.82 & 9.79 & 8.20 & 2.20 \\
Black & All sizes & 77.32 & 11.39 & 9.30 & 2.00 \\
gram & $<0.5$ & 46.00 & 44.70 & 7.40 & 1.90 \\
& $0.5-1.0$ & 27.60 & 67.50 & 4.10 & 0.80 \\
Green & $>1.0$ & 42.46 & 33.47 & 20.40 & 3.70 \\
gram & All sizes & 39.40 & 46.10 & 12.10 & 2.40 \\
& $<0.5$ & 48.10 & 43.70 & 2.40 & 5.80 \\
& $0.5-1.0$ & 31.80 & 4.10 & 64.10 & 0.00 \\
& $>1.0$ & 66.53 & 19.58 & 11.10 & 2.80 \\
& All sizes & 59.10 & 18.90 & 19.40 & 2.60
\end{tabular}

Note(s): National Sample Survey (NSS) 70th round

Shortage of pulses in India

Table 7.

Reported experiences of crop loss by cause in selected pulses

$(2012-13)$ 
JADEE 11,4

600 rupees less per quintal, but prefer that than going to the market where they have to pay for transportation and find buyers - Anus Sharma, team leader of Salkanpur and Narmadanchal Farmer Producer Organisation, Salkanpur, Madhya Pradesh

Factors influencing the ability of producers to link to markets and commercialize vary according to the crop yields, size of landholdings and the location of farms. As R\&D in pulses did not advance as much as it did for cereals and other cash crops and oilseeds such as cotton and soya, their yields have remained low, affecting the per unit costs of production, making competing crops more favorable. With low yields, the same small farms selling wheat, rice, cotton and soya may not participate in markets when growing pulses. When they participate, they may choose to transact with intermediaries for sale, reducing their price realization. The NSS data show that smaller the size of landholdings, lower the direct participation in markets in the case of pulses. Due to yield advantages in major cereals resulting from the green revolution, pulses cultivation moved out of irrigated tracts of the Indo Gangetic plains to the more semi-arid regions of central and East India with limited marketing, connectivity and irrigation infrastructure. The cultivation of pulse especially pigeon pea, therefore, have higher exposure to climatic risks and access to marketing infrastructure-increasing their PCTs, relative to other crops.

\subsection{Marketing of pulses- the influences of market power and information asymmetry}

Their specific characteristics of a particular crop determine the structure of its market. As mentioned earlier, perishable commodities may have shorter value chains and time constraints may condition the dynamic of the transaction. For non-perishable crops such as food grains, the value chains may be longer with a more significant number of intermediaries in them. For cereals such as wheat and rice, in order to minimize the influence of FCTs in price discovery, bargaining and screening, MSP and direct procurement by the state through the Food Corporation of India (FCI) were set up. These institutions brought about higher levels of integration in the marketing of wheat and rice. The markets for other food grains such as pulses and coarse grains, in contrast, have lower levels of integration. In these fragmented markets, intermediaries increase the search, negotiating and screening costs and lower the price realized by the sellers. In this section, we look at the structure of the pulses markets to assess the influence of asymmetric information and market power in determining transaction costs and price realized by sellers.

5.3.1 Intermediaries and asymmetric information in the pulses supply chain. The pulses markets in India are highly fragmented with a large number of intermediaries participating in them. Information asymmetry where the buyer and seller have different levels of information regarding prices, demand conditions, consumer preferences and future and current market trends that increases the gains of buyers over producers. This information asymmetry influences price realization, bargaining power, exposure to risk, moral hazard, shirking, cheating and add substantially to transaction costs (Bardhan, 1989). The two kinds of intermediaries in the pulses value chain are the traders/merchants and the brokers. In the absence of economies of scale resulting from the selling of pulses by a large number of small producers and no quality determining mechanisms, the primary role of traders and merchants is consolidating, sorting and grading of pulses. Traders with the lowest economic power are the petty traders who are the main aggregators at the village level at the farm gate and primary markets. Brokers mediate the sale of goods between a buyer and a seller on a commission for their services. Their primary role is to transmit information about availability, quality and price within markets, reducing the search cost for different merchants.

The absence of grades and standards in the agricultural markets in India accentuates the problem of asymmetric information (Pingali and Khwaja, 2004; Umali-Deininger and Sur, 
2007). Poor market information makes reference pricing of primary agricultural products arbitrary, leading to lower price realization for sellers. In pulses markets, the grade and quality are not objectively determined as many markets do not have infrastructure, expertise or established metrics or method of grading. It is also in the best interest of the intermediary not to have these facilities in the markets as grading and sorting is their primary activity. Traders purchase based on their content of immature seeds, foreign matter or cleanliness and moisture; clean, sort and grade them before selling it.

There are different qualities of pulses available in markets. Which quality do you want ...? If I want, I can get in-between qualities as well. Suppose one batch is for Rs. 95 and the other for Rs 90 , but I as a buyer want dal at Rs 93 . He can mix the 95 and the 90 qualities to make me an Rs. 93 quality. If I negotiate at Rs 95 and say I want it at Rs 94, he will give me the corresponding Rs. 94 quality. That is the reason I say it is an unorganized trade sector-Senior Manager, Sourcing, Corporate procurer

Brokers may not participate in buying and selling in the markets but play a crucial role in mediating transaction between buyer and seller. In a highly fragmented, differentiated and dispersed market, brokers convey and pass on information and reduce transaction costs to enable informed exchange. In the absence of established rules and regulations to guide transactions, the brokers fulfill these functions. The functions of traders and brokers are relevant in the absence of a regulatory framework and therefore they fight to maintain the status quo, where they fulfill a specific economic function.

5.3.2 Market power and transaction costs. Market power is determined by the ability to access markets, goods, labor and credit, depending on the actor's position in the institutions of society (Bowles and Gintis, 2007). Along with this, production status determined by the volume of marketable surplus at the household level influences the conditions under which the transaction takes place. When few buyers control demand and supply, resulting in oligopoly or oligopsony conditions - it increases transactions costs (Sexton, 2012), reduces welfare through adverse pricing and lower bargaining power (Hamilton and Feenstra, 1998) and increase the screening and negotiating cost to producers (Key et al., 2000a, b). The three main ways in which power is exercised in pulses markets were through interlinked contracts, collusion among buyers and hoarding. These forms of market power are not limited to the farmer and merchant interactions, but also between merchants and traders in different markets or within markets.

Trade-credit linkages formed when traders who buy produce or sell inputs such as seeds, fertilizers and pesticides extend credit to cultivators on the condition that they sell their produce at a fixed (often depressed) price on which the debt payment is adjusted [3] (Chaudhuri and Banerjee, 2004; Harriss-White and Bouman, 1994; Hoff and Stiglitz, 1990). In the presence of high costs or low availability of collateral to access institutional credit, farmers' dependence on traders for credit links is essential services that also their sales options through formal agencies and reduce price realization.

If you go to the bank, they will ask for collateral. They (traders) do not ask for collateral. Even if a government agency or a company wants to purchase/.../ they cannot purchase from the farmer...

(Because farmers are dependent on traders)-Senior Manager, Sourcing, Corporate procurer

Collusion among traders to set prices in a particular market is another way of exercising power. In exchanges that involve auctioning, buyers may collude to set prices below market price in order to maximize margins. In their study of cereal auctions in North India, Banerji and Meenakshi (2004, 2008), show how traders and merchants collude to depress buying prices in the market. Even in commodities where MSP's are announced, when market prices rise above MSP, collusion keeps prices close to MSP (Banerji and Meenakshi, 2004) and buyers may also depress prices below MSP citing poor quality (Meenakshi and Banerji, 2005). In the Bhopal APMC, traders set favorable price considering the announced MSP.

Shortage of pulses in India 


\section{JADEE 11,4}

426
We are not big traders and our margins are often small, so we have to decide what a fair price is on that day. Sometimes there are risks involved. You may think the quality is good but, in the end, when the farmer brings it to you, it may not be all that good. So, we need to consider that in the prices. The market price does not consider our margins or our risk, but we need to- Trader, Bhopal APMC

Joshi et al. (2016) argue that MSP benefits traders more as market prices are often higher than MSP for pulses and traders collude to keep buying prices closer to MSP, rather than actual market prices. Observing auctions in the Bankhedi and Pipariya markets of Madhya Pradesh revealed the difference between the announced market prices and the observed selling prices in 10 lots (Table 8). The difference in prices ranges from 6 to $22 \%$. The significantly higher power of buyers over sellers hinders price realization even in conditions when market prices are reported and sellers are aware of them.

Another factor influencing price transmission in the markets are hoarding practices by traders. In pulses, where price uncertainty is high, larger traders may hoard pulses when prices are low and release them in markets when prices are on the rise. The Essential Commodities Act makes the hoarding of pulses illegal and has created stock limits on storage. However, in 2015, 75,000 tonnes of pulses were seized from different traders in 13 states [4]. Cartel-like behavior of traders leads to reduced transmission of supply information that influence the asymmetries in price information. As wholesale prices are lower than retail prices, higher prices do not always translate to higher remuneration for farmers.

Figure 4 depicts the various processes in the markets in relation to changes in the price of pulses, the costs of participation, market failures and the benefits and services added at every stage of in the value chain. $\mathrm{P} 1$ to $\mathrm{P} 6$ depicts the changing prices of pulses from the primary producer to the final retailer. In the early stages of the marketing chain at the RPMs and secondary market stages, transactions costs are high due to market power in favor of buyers, inadequate information, low volume of produce and missing market mechanism such as grades and standards are pervasive. At the later stages of marketing, the market failures are lower. Here the transacted volumes are larger, grades and standards are determined objectively and in the absence of formal rules and regulation informal systems of sanctions prevent information asymmetry problems. As price margins are significant when each intermediary sell in the market, participants at the lower stages of the marketing chain are squeezed because as they have lower bargaining power and information. There are often up to six different changes in prices between farms and retailers. The price offered at the farm gate is, therefore, the lowest competitive price for pulses.

The pulses markets in India are highly fragmented with high fixed and proportional transactions costs in them. The literature on economic institutions have looked at traders and intermediaries as providing crucial services in situations of missing markets especially for credit and inputs (Bardhan and Rudra, 1978; Basu, 1997; Chaudhuri and Banerjee, 2004). In

\begin{tabular}{|c|c|c|c|}
\hline Market & Average market price & Observed selling prices (per lot) & Percentage difference \\
\hline \multirow[t]{3}{*}{ Bankhedi } & 7800 & 6250 & 22.06 \\
\hline & & 6700 & 15.17 \\
\hline & & 7200 & 8.00 \\
\hline \multirow[t]{7}{*}{ Pipariya } & 8000 & 6900 & 14.77 \\
\hline & & 7220 & 10.25 \\
\hline & & 7100 & 11.92 \\
\hline & & 7415 & 7.59 \\
\hline & & 7535 & 5.99 \\
\hline & & 6591 & 19.31 \\
\hline & & 6850 & 15.49 \\
\hline
\end{tabular}

Table 8.

Difference between market and selling prices of Pigeon pea on 15th March 2016 in Bankhedi and Pipariya markets, MP 


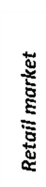

$\frac{\sqrt[n]{0}}{\frac{\pi}{\pi}}$

Shortage of

: pulses in India

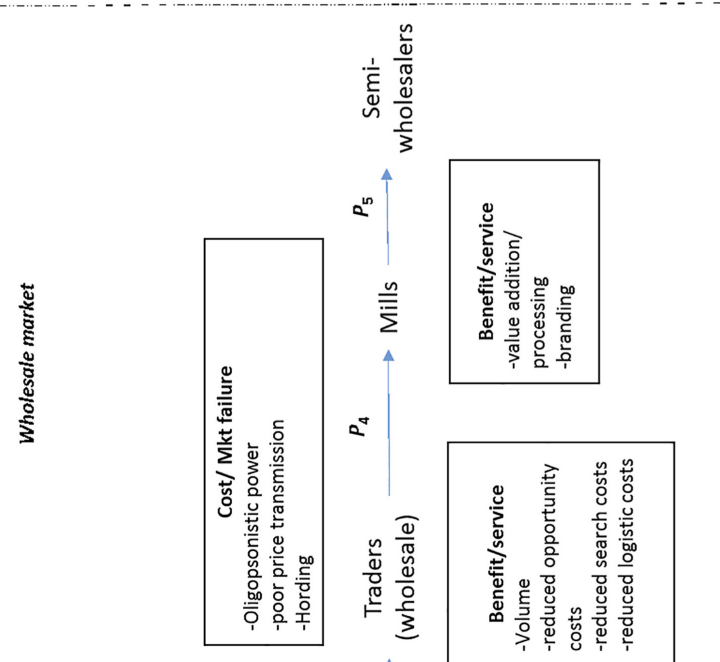

427

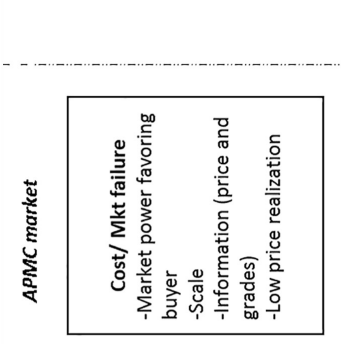

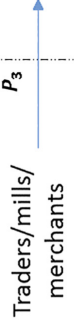

$0^{2}$
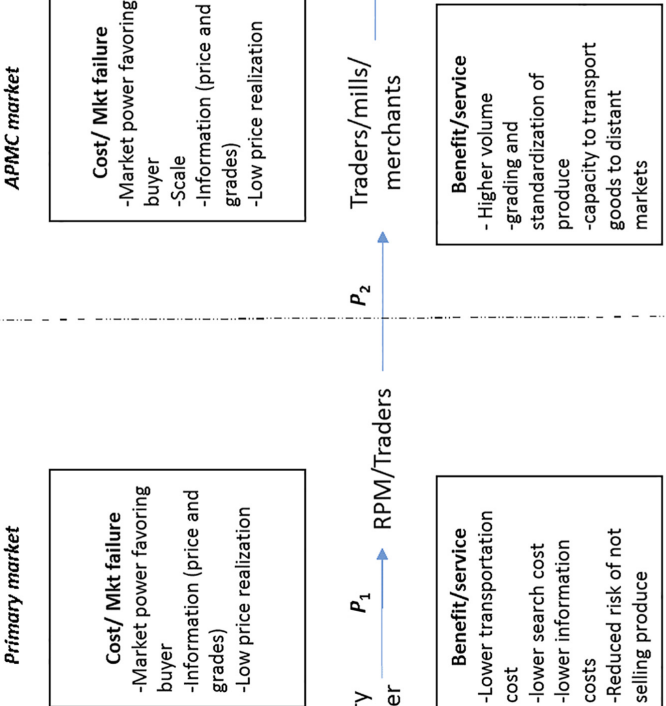

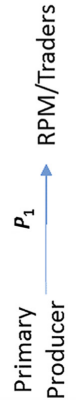

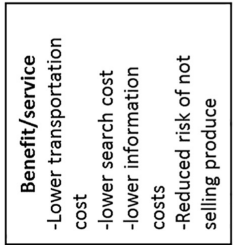

Figure 4

Price transmission and the nature of costs and benefits in the pulses value chain 
JADEE 11,4

the absence of services such as grades and standards and also by consolidating produce when variable transaction costs are high due to low yields, the small size of farms and geographical disadvantages they provide essential services. However, intermediaries also play an exploitative role by exercising market power in the form of oligopsonies, collusion and hoarding. It is also in their best interest that services such as aggregation and grades and standards do not emerge.

\section{Recommendations and conclusions}

In this paper, we assess production level factors and market-level factors that influence the supply response of pigeon pea, black gram and green gram, the main Kharif pulses grown in India. The link between the level of commercialization of farms and access to markets incentivize supply response at the farm level. The supply response model shows that the area response to price is mostly inelastic, but is influenced by yield and prices of competing crops and access to irrigation and rainfall. The farm-level incentive to invest in technology, quality inputs, infrastructure such as irrigation is conditioned on the price realization and levels of market engagement. If pulses cultivation remains semi-commercial, where farmers' engagement with markets is limited and supply responses pick up only when prices are unrealistically high, the volatility in prices and availability will remain. Addressing issues of market access by reducing proportional and fixed transactions costs will be important. Based on the evidence gathered in this paper we recommend institutional interventions to better promote aggregation models and market reforms to address issues of transaction costs as essential to increase commercialization of pulses production.

Aggregation models and vertical coordination mechanisms are potential interventions that may help redress the disadvantages of small farms. Farmer Producer Organizations (FPOs) and cooperatives are examples of aggregation models where small and marginal producers voluntarily organize themselves as a group to achieve a common aim. Empirical evidence has shown that aggregation initiatives among small farms have helped improve access to markets and inputs such as seeds, credit, fertilizer and pesticides, technology and extension services (Bellemare, 2012; Birthal et al., 2009; Narayanan, 2014; Sathapatyanon et al., 2018; Wang et al., 2014). Promoting them more widely could help smallholders reduce proportional and FCTs that limit smallholder market participation. Aggregation models in the past have met with limited success in many developing countries. Recent successful aggregation models have been those with good market linkages and vertical coordination that incentivizes producers to cooperate.

Alternative markets such as online marketing platforms, commodity futures and warehousing have the potential to disperse price risks and reduce transaction costs. Karnataka's Rashtriya eMarket Services Pvt.Ltd, (ReMS) and the e-nam model it inspired can be possible solutions for structural challenges of agricultural markets. ReMS has led to increased market bids in auctions, reduced collusion among traders and cartels, increased transparency in transactions and reduced delays in payments compared to non-e-markets (A. Reddy, 2016). E-nam, a national level initiative can help price discovery across markets in India, enable a harmonized grading and standards system and for a transparent transaction, bypassing intermediaries. They can also encourage increased private sector participation for vertical coordination. The uptake of trading on virtual platforms has however been slow with only 585 APMCs (9\% of markets) in 14 states currently connected. Commodity futures markets and warehousing of agricultural commodities are provisions that exist in the agricultural commodity space that again has not been widely accessed (Dey and Maitra, 2016). The reason being low economies of scale for smallholders. Through commodity exchanges, a producer or aggregator can agree to sell agricultural produce at a predetermined fixed price at a fixed location to a buyer. Through warehousing systems, farmers 
can address the issues of distress sales or selling when prices are low, by storing their produce against a warehouse receipt; as a derivative that can be traded or put up as collateral with banks for immediate cash needs. The advantages of warehousing are reduced handling costs, higher price realization and the ability to buy and sell without physical transfer. The significant challenges for smallholder participation in these platforms are infrastructure based and related to scale. Access and connectivity to warehouses and collection points is a concern for producers. Linking aggregation models with these marketing options can help address this.

In many states such as Odisha, Assam, Jharkhand and Chhattisgarh, $82 \%$ of the land is left fallow in the post-paddy season due to high opportunity costs of farming (P. K. Joshi and Rao, 2017; N. Singh et al., 2016). The regions that have biophysical conditions ideal for the growing pulses can gain from farm-level diversification of production increasing the supply of pulses. Commercialization and better price realization can help offset farm-level opportunity costs to encourage cultivation in post-paddy season. Reducing transaction costs and improving options for commercialization can help bring about stronger supply response. It could potentially stimulate farm-level investments in technology, quality inputs; respond to irrigation infrastructure without switching to competing crops.

\section{Notes}

1. Pulses are a group of leguminous crops comprising of dried beans, lentils and peas. Crops that are harvested green such as green peas and green beans and crops used primarily for oil such as soya bean and groundnuts, although leguminous are not considered pulses.

2. Source: Directorate of Economic and Statistics, DAC\&FW

3. The other forms of interlinking are land-labor linkages (Bharadwaj and Das, 1975) and land-credit linkages (Bardhan, 1980; Bardhan and Rudra, 1978; Majid and Nadvi, 1987).

4. http://timesofindia.indiatimes.com/india/Nearly-75000-tonnes-of-pulses-seized-from-hoarders-in-13states-so-far/articleshow/49518834.cms

\section{References}

Acharya, S.S. (2006), "Agricultural marketing and rural credit for strengthening agriculture”, INRM Policy Brief No 3, Asian Development Bank India Resident Mission (INRM), New Delhi.

Alagh, M. (2004), "Aggregate agricultural supply function in India", Economic and Political Weekly, Vol. 39 No. 2, pp. 202-206, available at: http://www.jstor.org/stable/4414502.

Ashok (2004), "Supply response of Cassava in Tamil Nadu", Indian Journal of Agricultural Economics, Vol. 27 Nos 67-73.

Banerji, A. and Meenakshi, J.V. (2004), "Buyer collusion and efficiency of government intervention in wheat markets in Northern India: an asymmetric structural auctions analysis", American Journal of Agricultural Economics, Vol. 86 No. 1, pp. 236-253, doi: 10.1111/j.0092-5853.2004. 00575.x.

Banerji, A. and Meenakshi, J.V. (2004), "Millers, commission agents and collusion in grain markets: evidence from basmati auctions in North India", The B.E. Journal of Economic Analysis and Policy, Vol. 8 No. 1, doi: 10.2202/1935-1682.1786.

Bardhan, P. (1980), "Interlocking factor markets and Agrarian development: a review of issues", Oxford Economic Papers, Vol. 32 No. 1, pp. 82-98, available at: http://www.jstor.org/stable/ 2662618.

Bardhan, P. (1989), "Alternative Approaches to the theory of institutions in economic development", in Bardhan, P. (Ed.), The Economic Theory of Agrarian Institutions, Oxford University Press, New York, NY, pp. 3-17. 
JADEE 11,4

Bardhan, P. and Rudra, A. (1978), "Interlinkage of land, labour and credit relations: an analysis of village survey data in east India”, Economic and Political Weekly, Vol. 13 No. 6/7, Annual Number, pp. 367-384, available at: http://www.jstor.org/stable/4366362.

Barrett, C.B., Bachke, M.E., Bellemare, M.F., Michelson, H.C., Narayanan, S. and Walker, T.F. (2012), "Smallholder participation in contract farming: comparative evidence from five countries", World Development, Vol. 40 No. 4, pp. 715-730, doi: 10.1016/j.worlddev.2011.09.006.

Basu, S. (1997), "Why institutional credit agencies are reluctant to lend to the rural poor: a theoretical analysis of the Indian rural credit market", World Development, Vol. 25 No. 2, pp. 267-280, doi: 10.1016/S0305-750X(96)00103-9.

Behrman, J.R. (1968), Supply Response in Underdeveloped Agriculture: A Case Study of Four Major Annual Crops in Thailand 1937-63, North Holland Publishing, Amsterdam.

Bellemare, M.F. (2012), "As you sow, so shall you reap: the welfare impacts of contract farming", World Development, Vol. 40 No. 7, pp. 1418-1434, doi: 10.1016/j.worlddev.2011.12.008.

Benjamin, D., Reardon, T., Stamoulis, K.G. and Winters, P. (2002), Promoting Farm/non-Farm Linkages for Rural Development - Case Studies from Africa \& Latin America, Food and Agriculture Organisation, The United Nations, Rome.

Bharadwaj, K. (1985), "A view on commercialisation in Indian agriculture and the development of capitalism", Journal of Peasant Studies, Vol. 12 No. 4, pp. 7-25.

Bharadwaj, K. and Das, P.K. (1975), "Tenurial conditions and the mode of exploitation in some villages in Orissa", Economic and Political Weekly, Vol. 10 Nos 25/26, pp. A49-A55.

Bhattarai, S., Lyne, M.C. and Martin, S.K. (2013), "Assessing the performance of a supply chain for organic vegetables from a smallholder perspective", Journal of Agribusiness in Developing and Emerging Economies, Vol. 3 No. 2, pp. 101-118, available at: https://search.proquest.com/ docview/1449425116? accountid $=10267$.

Birthal, P.S., Jha, A.K., Tiongco, M.M. and Narrod, C. (2009), "Farm-level impacts of vertical coordination of the food supply chain: evidence from contract farming of milk in India", Indian Journal of Agricultural Economics, Vol. 64 No. 3, pp. 481-496, available at: http://search. proquest.com/docview/201483208? accountid $=10267$.

Bowles, S. and Herbert, G. (2007), "Power," Paper no 37, Economics Department Working Paper Series, University of Massachusetts Amherst, available at, Vol. 39 No. 2, pp. 327-348, available at: https://scholarworks.umass.edu/cgi/viewcontent.cgi?article $=1039 \&$ context $=$ econ_ workingpaper.

Chaudhuri, S. and Banerjee, A.K. (2004), "Credit-product interlinkage, captive markets and trade liberalization in agriculture: a theoretical analysis", Indian Economic Review, Vol. 39 No. 2, pp. 327-348, available at: http://www.jstor.org/stable/29793819.

Cummings, J. (1975), "The supply responsiveness of indian farmers in the post-independence period: major cereal andcash crops", Indian Journal of Agricultural Economics, Vol. 30 No. 1, pp. 25-40.

de Janvry, A. and Sadoulet, E. (2006), "Progress in the modelling of rural households' behavior under market failure", in de Janvry, A. and Kanbur, R. (Eds), Poverty, Inequality and Development, Essays in Honor of Erik Thorbecke, Springer, Boston, MA.

de Janvry, A., Fafchamps, M. and Sadoulet, E. (1991), "Peasant household behaviour with missing markets: some paradoxes explained”, Economic Journal, Vol. 101` No. 409.

Desai, B. and Nambooditi, N. (1997), "Price and non-price determinants of aggregate agricultural supply", in Desai, B. (Ed.), Agricultural Development Paradigm in the Ninth Plan Unde New Economic Environment, Oxford University Press \& IBH, Delhi.

Deshingkar, P. (2010), "Migration, remote rural areas and chronic poverty in India", ODI Working paper No. 323.

Dey, K. and Maitra, D. (2016), "Can futures markets accommodate Indian farmers?", Journal of Agribusiness in Developing and Emerging Economies, Vol. 6 No. 2, pp. 150-172, doi: 10.1108/ JADEE-08-2013-0029. 
Donovan, J., Franzel, S., Cunha, M., Gyau, A. and Mithöfer, D. (2015), "Guides for value chain development: a comparative review", Journal of Agribusiness in Developing and Emerging Economies, Vol. 5 No. 1, pp. 2-23, doi: 10.1108/JADEE-07-2013-0025.

Goetz, S.J. (1992), "A selectivity model of household food marketing behaviour in sub-Saharan Africa", American Journal of Agricultural Economics, Vol. 74 No. 2, pp. 444-452.

Goldman, A. and Smith, J. (1995), "Agricultural transformations in India and Northern Nigeria: exploring the nature of green revolutions", World Development, Vol. 23 No. 2, pp. 243-263, doi: 10.1016/0305-750X(94)00115-F.

Haberfeld, Y., Menaria, R.K., Sahoo, B.B. and Vyas, R.N. (1999), "Seasonal migration of rural labor in India”, Population Research and Policy Review, Vol. 18 No. 5, pp. 471-487, doi: 10.1023/A: 1006363628308.

Hamilton, G.G. and Feenstra, R.C. (1998), "Varieties of hierarchies and markets: an introduction", in Dosi, G., Teece, D.J. and Chytry, J. (Eds), Technology, Organization, and Competitiveness: Perspectives on Industrial and Corporate Change, Oxford University Press, doi: 10.1093/ 0198290969.003.0004.

Harriss-White, B. and Bouman, F.J.A. (1994), "The question of traders as credit agents in India”, in Bouman, F.J.A. and Hospes, O. (Eds), Financial Landscapes Reconstructed: The Fine Art of Mapping Development, pp. 325-340.

Harriss-White, B. and Garikipati, S. (2008), "India's semi-arid rural economy: livelihoods, seasonal migration and gender", The European Journal of Development Research, Vol. 20 No. 4, pp. 547-548, doi: 10.1080/09578810802493267.

Hazell, P., Poulton, C., Wiggins, S. and Dorward, A. (2010), "The future of small farms: trajectories and policy priorities", World Development, Vol. 38 No. 10, pp. 1349-1361, doi: 10.1016/j.worlddev. 2009.06.012.

Hoff, K. and Stiglitz, J.E. (1990), "Imperfect information and rural credit markets - puzzles and policy perspectives”, World Bank Economic Review, Vol. 4 No. 3, pp. 235-250.

Joshi, P.K. and Rao, P.P. (2017), "Global pulses scenario: status and outlook", Annals of the New York Academy of Sciences, Vol. 1392 No. 1, pp. 6-17, doi: 10.1111/nyas.13298.

Joshi, P., Kishore, A. and Roy, D. (2016), "Making pulses affordable again policy options from the farm to retail in India”, IFPRI Discussion Paper No. 01555, South Asia Office, New Delhi.

Kanwar, S. (2006), "Relative profitability, supply shifters and dynamic output response, in a developing economy”, Journal of Policy Modeling, Vol. 28 No. 1, pp. 67-88, doi: 10.1016/j.jpolmod. 2005.06.014.

Key, N., Sadoulet, E. and de Janvry, A. (2000a), "Transaction costs and agricultural household supply response", American Journall of Agricultural Economics, Vol. 82 No. 2, pp. 245-259.

Key, N., Sadoulet, E. and de Janvry, A. (2000b), “Transactions costs and agricultural household supply response", American Journal of Agricultural Economics, Vol. 82 No. 2, pp. 245-259, doi: 10.1111/ 0002-9092.00022.

Kumar, N. and Kapoor, S. (2014), "Study of consumers' behavior for non-vegetarian products in emerging market of India", Journal of Agribusiness in Developing and Emerging Economies, Vol. 4 No. 1, pp. 59-77, available at: https://search.proquest.com/docview/1536600977? accountid $=10267$.

Majid, N. and Nadvi, K.M. (1987), "Agrarian transition in sind: an analysis of interlinked rural factor markets”, The Pakistan Development Review, Vol. 26 No. 4, pp. 433-446.

McCullough, E.B., Pingali, P. and Stamoulis, K.G. (2008), "Small farms and the transformation of food systems: an overview", in McCullough, E.B., Pingali, P. and Stamoulis, K.G. (Eds), The Transformation of Agri-Food Systems: Globalisation, Supply Chains, and Smallholder Farmers, Food and Agriculture Organisation, The United Nations, Rome, pp. 3-46. 
JADEE 11,4

Meenakshi, J.V. and Banerji, A. (2005), "The unsupportable support price: an analysis of collusion and government intervention in paddy auction markets in North India”, Journal of Development Economics, Vol. 76 No. 2, pp. 377-403, doi: 10.1016/j.jdeveco.2004.02.001.

Mungekar, B. (1997), "Terms of trade, technology and agricultural development”, in Desai, B. (Ed.), Agricultural Development Paradigm in the Ninth Plan Unde New Economic Environment, Oxford University Press \& IBH, Delhi.

Narayanan, S. (2014), "Profits from participation in high value agriculture: evidence of heterogeneous benefits in contract farming schemes in Southern India”, Food Policy, Vol. 44, pp. 142-157, doi: 10.1016/j.foodpol.2013.10.010.

Nerlove, M. (1958), The Dynamics of Supply: Estimation of Farm Supply Response to Price, John Hopkins University Press, Baltimore, Maryland.

Palanivel, T. (1995), "Aggregate supply response in Indian agriculture: some empirical evidence and policy implications", Indian Economic Review, Vol. 30 No. 2, pp. 251-263, available at: http:// www.jstor.org/stable/29793722.

Parikh, A. (1972), "Market responsiveness of peasant cultivators: some evidence from prewar India", The Journal of Development Studies, Vol. 8 No. 2, pp. 291-306, doi: 10.1080/00220387208421403.

Pingali, P. (2007), "Westernization of Asian diets and the transformation of food systems: implications for research and policy", Food Policy, Vol. 32 No. 3, pp. 281-298, doi: 10.1016/j.foodpol.2006. 08.001 .

Pingali, P. (2010), “Chapter 74 agriculture renaissance: making 'agriculture for development' work in the 21st century", in Evenson, R.E. and Pingali, P. (Eds.), Elsevier, Vol. 4, pp. 3867-3894, doi: 10. 1016/S1574-0072(09)04074-2.

Pingali, P. and Khwaja, Y. (2004), "Globalisation of Indian diets and the transformation of food supply systems", ESA Working Paper No. 04-05. (FAO: Rome, Italy, 2004) (ESA Working Paper No. 4-5), Rome.

Pingali, P. and Rosegrant, M.W. (1995), "Agricultural commercialization and diversification: processes and policies”, Food Policy, Vol. 20 No. 3, pp. 171-185, doi: 10.1016/0306-9192(95)00012-4.

Pingali, P., Khwaja, Y. and Madelon, M. (2005), "Commercializing small farms: reducing transaction cost", ESA Working Paper $\{$ No $\}, 05-08$.

Rahman, A. (2015), "Is price transmission in the Indian pulses market asymmetric?", Journal of Quantitative Economics, Vol. 13, pp. 129-146.

Reddy, A.A. (2009), "Pulses production technology: status and way forward", Economic and Political Weekly, Vol. 44 No. 52, pp. 73-80.

Reddy, A. (2016), "Impact of E-markets in Karnataka, India”, Indian Journal of Agricultural Marketing, Vol. 30 No. 2.

Routroy, S. and Behera, A. (2017), "Agriculture supply chain”, Journal of Agribusiness in Developing and Emerging Economies, Vol. 7 No. 3, pp. 275-302, doi: 10.1108/JADEE-06-2016-0039.

Sadasivan, S. (1989), "Patterns of pulses production - an analysis of growth trends", Indian Economic and Political Weekly, Vol. 24, pp. 51-52.

Sadasivam, S. (1993), "Price and non price factors in input use and output supply A case of gram in Uttar Pradesh", Indian Economic Review, Vol. 28 No. 1, pp. 73-83, available at: http://www.jstor. org/stable/29793638.

Sathapatyanon, J., Kuwornu, J.K.M., Shivakoti, G.P., Soni, P., Anal, A.K. and Datta, A. (2018), "The role of farmer organizations and networks in the rice supply chain in Thailand", Journal of Agribusiness in Developing and Emerging Economies, Vol. 8 No. 3, pp. 554-578, doi: 10.1108/ JADEE-01-2017-0016.

Sexton, R.J. (2012), "Market power, misconceptions, and modern agricultural markets", American Journal of Agricultural Economics, Vol. 95 No. 2, pp. 209-219, available at: http://ajae. oxfordjournals.org/content/by/year. 
Singh, O. (1998), "Growth and supply response of oilseeds in Uttar Pradesh", Situation in India, Vol. 55 No. 1.

Singh, N., Praharaj, C. and Sandhu, J. (2016), "Utilizing untapped potential of rice fallow of East and Shortage of
pulses in India North-east India through pulse production", Indian Journal of Genetics and Plant Breeding, Vol. 76 No. 4.

Thamarajakshi, R. (1994), Intersectoral Relationships in a Developing Economy, Academic Foundation, Delhi.

Thorat, S. (2009), "Economic exclusion and poverty linkages: a reflection on concept, consequences, and remedies in an Asian context", in von Braun, J., Hill, R.V. and Pandya-Lorch, R. (Eds), The Poorest and Hungry Assessments, Analyses, and Actions, International Food Policy Research Institute, Washington, DC.

Thorat, S. and Newman, K.S. (2007), "Caste and economic discrimination: causes, consequences and remedies", Economic and Political Weekly, Vol. 42 No. 41, pp. 4121-4124.

Tschirley, D.L., Snyder, J., Dolislager, M., Reardon, T., Haggblade, S., Goeb, J. and Meyer, F. (2015), "Africa's unfolding diet transformation: implications for agrifood system employment", Journal of Agribusiness in Developing and Emerging Economies, Vol. 5 No. 2, pp. 102-136, doi: 10.1108/ JADEE-01-2015-0003.

Tuteja, U. (2006), "Growth performance and acreage response of pulse crops: a state-level analysis", Indian Journal of Agricultural Economics, Vol. 61 No. 2.

Umali-Deininger, D. and Sur, M. (2007), "Food safety in a globalizing world: opportunities and challenges for India”, Agricultural Economics, Vol. 37, pp. 135-147, doi: 10.1111/j.1574-0862.2007. 00240.x.

Wang, H.H., Wang, Y. and Delgado, M.S. (2014), "The transition to modern agriculture: contract farming in developing economies", American Journal of Agricultural Economics, Vol. 96 No. 5, pp. 1257-1271, available at: http://ajae.oxfordjournals.org/content/by/year.

Yu, B., Liu, F. and You, L. (2012), "Dynamic agricultural supply response under economic transformation: a case study of Henan, China”, American Journal of Agricultural Economics, Vol. 94 No. 2, pp. 370-376, doi: 10.1093/ajae/aar114. 
JADEE 11,4

\section{Appendix}

\begin{tabular}{lll}
\hline Pulses & State & Competing crop \\
\hline Pigeon pea & Gujarat & Cotton \\
& Karnataka & Maize \\
& Madhya Pradesh & Soya \\
& Andhra Pradesh & Maize \\
& Uttar Pradesh & Maize \\
Black gram & Maharashtra & Cotton \\
& Madhya Pradesh & Soya \\
& Uttar Pradesh & Rice \\
& Andhra Pradesh & Maize \\
& Rajasthan & Cotton \\
& Tamil Nadu & Cotton \\
Green gram & Maharashtra & Cotton \\
& Rajasthan & sotto \\
& Madhya Pradesh & Maize \\
& Maharashtra & Soya \\
& Karnataka & Maize \\
& Odisha & Urad \\
\hline
\end{tabular}

Table A1.

Major pulses growing states in India and their competing crops

\section{4}

\begin{tabular}{|c|c|c|c|c|}
\hline \multirow[b]{2}{*}{$\begin{array}{l}\text { Table A2. } \\
\text { Villages studied for the } \\
\text { first phase of fields } \\
\text { work in Bihar, Odisha } \\
\text { and Uttar Pradesh }\end{array}$} & \multicolumn{2}{|c|}{ State and district } & \multicolumn{2}{|l|}{ Villages } \\
\hline & \multicolumn{2}{|c|}{$\begin{array}{l}\text { Munger District, Bihar } \\
\text { Kandhamal District, Odisha }\end{array}$} & \multicolumn{2}{|c|}{$\begin{array}{l}\text { Raghunathpur (20), Nayatola (18), Saradhi (15), Khopawar (21) } \\
\text { Tandalnaju (11), Dandikia (11), Damengi (15), Jakamaha (11), Burupati (11), } \\
\text { Dadadimaha (9) } \\
\text { Rangpur (22), Shivkot (16), Kamnaha (16), Belauha (11), Vishrampur (12), } \\
\text { Harivanshpur (15) }\end{array}$} \\
\hline \multirow[b]{2}{*}{$\begin{array}{l}\text { Table A3. } \\
\text { Markets and } \\
\text { Participants studied } \\
\text { during the first and } \\
\text { second phase of } \\
\text { fieldwork }\end{array}$} & State & Market & & Participants \\
\hline & $\begin{array}{l}\text { Delhi } \\
\text { Madhya } \\
\text { Pradesh }\end{array}$ & $\begin{array}{l}\text { Naya Baza1 } \\
\text { Bhopal, Pip } \\
\text { Rehti, Time }\end{array}$ & $\begin{array}{l}\text { ya, Bankhedi, } \\
\text {, Harda }\end{array}$ & $\begin{array}{l}\text { Millers (3), Traders (2) } \\
\text { Miller (1), Farmers (18), Civil society officials, Field officers } \\
\text { and extension agents (7), traders, Producer organizations } \\
\text { (5), APMC officials (4) } \\
\text { Millers (3), Corporate Procurers (3), Traders (7), Input } \\
\text { Merchant (1), Farmers (7), Producer Organizations (1), } \\
\text { APMC officials (3) }\end{array}$ \\
\hline
\end{tabular}

\section{Corresponding author}

Mathew Abraham can be contacted at: ma947@cornell.edu

For instructions on how to order reprints of this article, please visit our website:

www.emeraldgrouppublishing.com/licensing/reprints.htm

Or contact us for further details: permissions@emeraldinsight.com 